\title{
Pathogenic Fungi Transmitted Through Cucumber Seeds and Safely Elimination by Application of Peppermint Extract and Oil
}

\author{
Eman S. H. FARRAG ${ }^{1}$, Moustafa H.A. MOHARAM $^{2 *}$ \\ ${ }^{1}$ South Valley University, Faculty of Agriculture, Agricultural Botany Depart, Qena, Egypt \\ ${ }^{2}$ Sohag University, Faculty of Agriculture, Plant Pathology Depart, El-Kawther, Sohag P.O. \\ 82786,Egypt; moharam@hotmail.com (*corresponding author)
}

\begin{abstract}
Diseases induced by Fusarium, like damping-off and wilt on cucumber, are serious problems around the world. Samples of cucumber seeds were collected from commercial markets in Egypt and tested for seed-borne fungi. In order to detect the maximum number of internal and external seed-borne fungi, agar plate examination of disinfected and non-disinfected seeds were used. Two species of Fusarium were the most frequent and predominant fungi. Facultative parasites of the genera Alternaria, Rhizoctonia, Helminthosporium and Penicillium were also found. A total 33 isolates of Fusarium spp. were obtained using Komada's selective medium. Fusarium oxysporum and F. solani were highly frequent. Pathogenicity test indicated that, F. oxysporum isolate (Fem8) was the main causal organism of pre- and post-emergence damping off. Furthermore, it occurred in all seed parts tested. Some infected seeds germinate, but they were either rapidly overgrown by $F$. oxysporum or they developed into a diseased seedling. The water extract of garlic, peppermint and rheum completely inhibited the conidiospore germination and mycelial growth of F. oxysporum at tested conc. 3, 2 and 3\%, respectively. Soaked seeds in $2 \%$ peppermint extract and evaporated seeds by vapor of peppermint oil caused a highly reduction in the infection and reduced transmission of the referred fungi from seeds to the growing seedlings. The vigor of cucumber seedlings raised from the treated seeds was better than that developed from untreated ones.
\end{abstract}

Keywords: cucumber, elimination, Fusarium spp., peppermint oil, plant extracts, seed-borne fungi, transmission, vapour phase

\section{Introduction}

Seed is the most important input for crop production. Pathogen free healthy seeds are essential for desired plant populations and a good harvest. Of the $16 \%$ annual crop losses due to plant diseases, at least $10 \%$ loss occurs due to seed-borne diseases (Fakir, 1983). Coincidentally important or devastating crop diseases are seed-borne and caused by fungi. In addition, it has demonstrated that seed borne fungi are responsible for poor quality seeds in many crops (Neergaard, 1979). Seed-borne fungi causing plant diseases include Macrophomina phaseolina on soybean and maize (Raut, 1978; 1987; Singh and Kaiser, 1995), F. oxysporum on sesame (Patel and Patel, 1990), Aspergillus flavus, Alternaria tenuis and Rhizopus arrbizus on sunflower (Prasad and Kulshrestha, 1999), Fusarium spp. on watermelon (Boughallab et al., 2005; Boughalleb and El Mahjoub, 2006), Aspergillus sp., Fusarium sp. and Penicillium sp. on sorghum (Karim, 2005; Satish et al., 2010), Al. alternata, As. flavus, Curvularia lunata, F. oxysporum and $F$. solani on eggplant (Habib et al., 2007), and M. phaseolina on cucumber (Nasreen et al., 2009). Cucumber (Cucumis sativus $\mathrm{L}$.) is an important vegetable crop ranking fourth after potato, tomato and onion in Egypt. Approximately 2351.16 tons of cucumber fruits are produced from about 1199.52 hectares in Egypt through 2009 (FAO). Among severe fungal diseases, seed-borne pathogens are causing various factors responsible for the crop low yield. Important fungal diseases recorded on cucumber are dampingoff and wilt caused by $F$. oxysporum (Antoniou and Tjamos, 2000; Farrag and Fatouh, 2010). Studies are limited on seed-borne diseases of cucumber in Egypt. The seed borne fungal diseases are transmitted by seeds, where the fungi can survive as conidia or mycelia on the seed coat or surface (Blancart et al., 1991; Champion, 1997; Gargouri et al., 2000; Martyn and Bruton, 1989). Analysis of seed infection level is a valid investigation tool to foresee the disease development transmitted by seeds (Taylor $e t$ al., 2001). Few studies also have localized these pathogens on the seeds (Michail et al., 1989; 2002). Many seed-borne fungi are generally managed by synthetic chemicals, which are considered both efficient and effective. However, the continuous use of these fungicides started unraveling nonbiodegradability and is known to have residual toxicity causing pollution (Pimentel and Levitan, 1986). Pesticide pollution of the soil and water bodies is well documented (Nostro et al., 2000). Hence, in recent time application of plant extracts as well as plant metabolites for plant disease management has become important viable component of Integrated Pest Management, as plant metabolites are eco-friendly where botanicals place an important role (Sahayaraj et al., 2009). Several investigators have screened dif- 
84

ferent plants for their antifungal properties ( $\mathrm{Ja}$ Choi $e t$ al., 2004; Stephan et al., 2005; Satish et al., 2010), which are due to oil compounds synthesized by these plants. During the regular screening, a highly significant antifungal activity of some water extracts or essential oils of plants was recorded. Since some plants are already known to possess several biological activities (Amin et al., 2009; Barrera-Necha et al., 2009; Belabid et al., 2010; Farshabaf Moghadam et al., 2002), the objectives of this study were: (1) to isolate and identify Fusarium spp. from cucumber seeds, study its location in the seed and to elucidate its effect on seed germination and disease development. (2) to determine the Fusarium spp., load in each seed (3) to investigate in vitro the antifungal activity of some plant extracts on growth of F. oxysporum and (4) to introduce also the manual seed cleaning with these plant extracts and treating with their essential oil vapors for safely elimination of seed-borne transmitted fungi and reducing infestation level.

\section{Materials and methods}

The present investigation was conducted through 2010-2012 in the Depart. of Agric. Botany, Fac. of Agric., South Valley Univ. and Plant Pathol. Depart, Sohag Univ., Egypt. Seed samples of cucumber were collected from the commercial lots that used for sowing in the farms. Seeds were stored at room temperature (approx. $28^{\circ} \mathrm{C}$ and 50 $60 \%$ relative humidity, dry storage) until use and further they were subjected to initial seed health testing.

\section{Seed infection evaluation}

\section{Whole seed test}

Seeds were divided into two equal parts, the first: non-surface sterilized seeds, the second: disinfected ones by soaking in $1 \%$ sodium hypochlorite for $1 \mathrm{~min}$. The seeds were used in two experiments as follow. Initial seed health testing was conducted by agar plate method. Ten seeds were placed in Petri plates containing $20 \mathrm{ml}$ of Potato Dextrose Agar medium (PDA) and incubated at $25 \pm$ $2^{\circ} \mathrm{C}$ for seven days. After incubation, the Petri plates were examined for fungal growth under stereo-binocular microscope (Khare, 1996). In further experiment, seeds were evaluated for the presence of Fusarium spp. using selective medium (Komada, 1975). Isolation was performed for non-disinfected or disinfected seeds as mentioned above. Seeds infected by $F$. oxysporum were surrounded by characteristic fast-growing, fluffy, white fungal colonies that produced a red pigment. Fusarium oxysporum was identified and confirmed by conidial morphology examination (Domsch et al., 1980).

\section{Location of the pathogen in the seed}

Location of the pathogen $F$. oxysporum in the cucumber seeds was studied by employing component plating technique (Maden et al., 1975). Isolation was done on non-disinfected seeds or disinfected ones as mentioned above (fifteen seeds each). Seeds were washed four times with tap water and then surface sterilized as mentioned above. After that, the seeds were washed again with sterile distillated water (SDW) and soaked in water for $30 \mathrm{~min}$. On the other hand, another seed sample (non-disinfected) was soaked only in sterile distillated water for $30 \mathrm{~min}$. Seeds were dissected aseptically by sterile needles and forceps. The separated seed parts viz., seed coat, cotyledon and embryo were plated separately before drying on plates containing Komada selective medium and incubated at $25 \pm 2^{\circ} \mathrm{C}$ for seven days. The seed components were examined under stereo-binocular microscope for presence of the Fusarium in different seed parts. The number of contaminated parts was enumerated every 3 days for a period 15 days. The infection level in each seed part was evaluated according to the following formula:

Infection level $(\%)=$ total number of infected seed parts / total number of seed parts $\times 100$

The fungal colonies that appeared identical to Fusarium spp. around every seed part were transferred to PDA medium supplemented with $40 \mathrm{mgL}^{-1}$ streptomycin sulphate.

\section{Identification of the isolated fungi and the used isolates}

The isolated fungi from seeds were purified using single spore isolation technique and hyphal tip method and then were numbered Identification of the numbered isolates was done based on the spore morphology and colony characters referring to the 'Illustrated genera of Imperfect fungi' (Barnett and Hunter, 1972) and 'Demataceous hyphomycetes' (Ellis, 1971) and (Domsch et al., 1980). The pure cultures belonging to Alternaria, Fusarium, Helminthosporium, Penicillium and Rhizoctonia isolates were authenticated at Assiut University Mycology Centre (AUMC). Furthermore, the obtained pathogenic isolate $F$. oxysporum f. sp. cucumerinum (Farrag and Fatouh, 2010) was used as positive control. All isolates were maintained at $5^{\circ} \mathrm{C}$ on PDA slants for further studies.

\section{Pathogenicity tests}

The fungal inocula of the different isolates were prepared in shake culture at $25^{\circ} \mathrm{C}$ for 10 days. The culture suspension was filtered through one layer of cheese cloth. The concentration of spores was determined by hemacytometer and adjusted with SDW to $1 \times 10^{6}$ colony forming unit $(\mathrm{CFU}) / \mathrm{ml}$. The spore suspension was used as inoculum for pathogenicity test in two ways. The first way: cucumber seeds were sown in an autoclaved soil mixture (peat, compost and clay, respectively, 60:20:20 v/v/v) in plug trays and maintained at $25^{\circ} \mathrm{C}$, with $12 \mathrm{~h}$ /day of fluorescent light. Roots of 15-day-old plants were washed, trimmed to $5 \mathrm{~cm}$ length, and then dipped in the spore suspension for $10 \mathrm{~min}$. Inoculated plants were transplanted in pots filled with steamed soil (1.5 L volume). Control plants were prepared similarly but soaked in SDW. Six replicates were used and each replicate consisted of five plants. The experiment was carried out under glasshouse 
conditions at temperature ranging between $30-34^{\circ} \mathrm{C}$. Plants were checked daily and the typical symptoms of Fusarium wilt in positive control that started to be visible 10 days after inoculation. The wilted plants were counted and the percentage of died plants were calculated after 30 days of inoculation.

The second way: cucumber seeds were surface sterilized as descried before. After washing seeds with sterile distillated water, seeds were soaked in the fungal spore suspension for $5 \mathrm{~min}$. After that, seeds were air dried immediately and then were cultivated in pots filled with steamed soil. Six seeds were sown per pot and ten pots were used. Soaked seeds in the SDW served as control. Data were calculated as percentage of germination, pre- and post-emergence damping-off 10,15 and 40 days after sowing, respectively. In addition, the number of plants survived was also recorded. The data obtained were statistically analyzed using complete randomized design and means were compared using L.S.D. test according to Gomez and Gomez (1984).

\section{Paper towel (Rolled towel) method}

Paper towel (Rolled towel) method was employed to know the effect of seed-borne inoculum on seed quality parameters of cucumber i.e. to carry out germination and vigor tests. In addition, to investigate the efficacy of seed treatments against seed-borne fungal inoculum according to the International Seed Testing Association Rules (Anonymous, 1996). Randomly selected 100 seeds were placed on two layers of moist papers, which were placed on a polythene page, and ten seeds per row were used. The seeds were covered with another moist paper and rolled carefully to avoid any excess pressure on seeds. These towels were incubated at $25^{\circ} \mathrm{C}$ under $12 \mathrm{~h}$ light and $12 \mathrm{~h}$ darkness for ten days. Seed germination was recorded after 4 and 10 days of incubation. All the morphologically normal seedlings were counted and the percentage of germination was calculated. To find out the seedling vigor, ten normal seedlings were taken from the germination test at random. The root length $(\mathrm{cm})$ was measured from the collar region to the tip of the primary root and the mean root length was calculated. The same seedlings were used for the measurement of shoot length. In addition, the shoot length $(\mathrm{cm})$ was measured from the collar region to the point of junction of the cotyledons. The mean shoot length was recorded. Vigor index was calculated using the following formula, given by Abdul Baki and Anderson (1973):

Vigor index $=$ Seed germination $(\%) \times$ Seedling Length (Shoot + Root Length)

\section{Overcoming seed-borne fungi of cucumber}

A-Efficacy of some plant extracts on the condiospore germination and mycelial growth of $F$. oxysporum in vitro

The efficacy of some plant extracts listed in Tab. 1 was screened on the base of spore germination and inhibition of linear growth in vitro. Plant extracts were prepared by stirring $10 \mathrm{~g}$ of the plant powder in $100 \mathrm{ml}$ heated tap wa- ter $\left(50^{\circ} \mathrm{C}\right)$ for an hour, followed by centrifugation at 1453 g and $5^{\circ} \mathrm{C}$ for $10 \mathrm{~min}$. The supernatant was added to warm $\left(45^{\circ} \mathrm{C}\right)$, sterilized PDA medium before solidification to obtain final concentrations of 1,2 and 3\%. The controls were PDA medium amended with sterile distilled water instead of plant extracts. The plates were inoculated with 1 $\mathrm{ml}$ of spore suspension $\left(10^{5}\right.$ conidia $\left.\mathrm{mL}^{-1}\right)$ and then incubated at $20^{\circ} \mathrm{C}$ for 24 hours. Following spore staining with lactophenol blue, the germination was checked microscopically. Four replicates for each treatment were used.

Fifty spores per each replicate were examined and the percentage of germinated spores was calculated. Other plates were inoculated with fungal disc $(6 \mathrm{~mm}$ in diameter) and then incubated at $25 \pm 2^{\circ} \mathrm{C}$ till control plates (free plant extracts) reached the radial growth of $90 \mathrm{~mm}$, the mycelium was checked microscopically. Percentage of inhibition over control was also calculated.

\section{B-Elimination of $F$. oxysporum from infected seeds of cucumber}

Efficacy of the most inhibitory plant extracts was also investigated for eliminating seed-borne inocula of F. oxysporum from infected seed samples by paper towel method as described before. In each treatment, 100 seeds were soaked in $100 \mathrm{ml}$ of 3,2 and $3 \%$ of garlic, peppermint and rheum extract, respectively for $15 \mathrm{~min}$ and then shade dried for $24 \mathrm{~h}$. Seeds soaked in sterile distilled water served as control. The treated seeds were tested in four replications, then incubated at $25 \pm 2^{\circ} \mathrm{C}$ for ten days under $12 \mathrm{~h}$ light and $12 \mathrm{~h}$ darkness. The germinated seeds were counted and percentages of germination and infection were computed. Seedling vigour index was also calculated.

\section{C-In vitro evaluation of peppermint oil by paper towel method}

For extraction peppermint crude oil, steam distillation of wilted leaves was used and the oil was distillated using a Clevenger type apparatus (Gunter, 1948). Seeds were soaked in $100 \mathrm{ml}$ of oil emulsions (1,2 and 3\%) for $15 \mathrm{~min}$ and then dried in shade for $1 \mathrm{~h}$. Seeds soaked in sterile distilled water served as control. The treated seeds were tested in four replications of 100 seeds by employing paper towel method, and then incubated at $25 \pm 2^{\circ} \mathrm{C}$ for ten days. The percentages of germination and infection were calculated after ten days of incubation. Seedling vigour index was also calculated.

\section{D-In vitro evaluation the vapour phase of peppermint oil}

To evaluate the vapor phase of peppermint oil for eliminating $F$. oxysporum from infected seeds, doses of 5 , 10 and $15 \mu \mathrm{l}$ oil were applied to a filter paper $(100 \mathrm{~mm}$ in diameter). After that, the filter paper was mounted on the inverted lid in a Petri dish $(140 \mathrm{~mm} \times 23 \mathrm{~mm}$, which offers $400 \mathrm{Ml}$ air space). The tested seeds (100 per each treatment) were placed in each dish. The dishes were sealed with vinyl tape and left at $30^{\circ} \mathrm{C}$ for $48 \mathrm{~h}$. Seeds not exposed to oil vapors were served as control. The treated seeds were 
Tab. 1. List of some plant extracts used in this study

\begin{tabular}{ccc}
\hline Name of plant & Form & Manufacturer/Distributor \\
\hline Common walnut (Juglans regia) & Powder leaves & ditto \\
Cowslip (Primula veris) & Powder roots & Galke GmbH, Gittelde, Germany \\
Garlic (Allium sativum) & Granules & FUCHS edle Gewürze, Dissen, Germany \\
Goldenrod (Solidago canadesis) & Powder stem & Alfred Galke GmbH, Gittelde, Germany \\
Mugwort (Artemisia vulgaris) & Powder leaves & ditto \\
Nettle (Urtica dioica) & Powder leaves & ditto \\
Peppermint (Mentha piperita) & Powder leaves & Organic Herbspices, Minia, Egypt \\
Rheum (Rheum rhabarbarum) & Powder stem & Alfred Galke GmbH, Gittelde, Germany \\
Salvia (Salvia officinalis) & Powder leaves & ditto \\
Soapwort (Saponaria officinalis) & Powder stem & ditto \\
\hline
\end{tabular}

sown in pots filled with steamed soil and the pots were left at $25^{\circ} \mathrm{C}$. Six seeds per pot and ten pots per each treatment were used. Percentages of pre- and post- emergence damping-off were calculated 15 and 40 days after sowing, respectively. The percentage of survival plants was also calculated at the end of the experiment.

\section{Results}

\section{Evaluation of seed health testing methods}

The results presented in Tab. 2 indicate that among the two different media employed for detecting of seed-borne fungal infection, PDA medium was found to be very good for detecting Rhizoctonia sp., Penicillium spp., Alternaria sp. and Helinthosporium sp. On the other hand, Komada selective medium was found better than PDA for detecting Fusarium spp. in the majority of seed lots (25 and 32\% occurrence), where the growth was more sensitive than of PDA medium (28 and 20.7\% occurrence). Finally, PDA medium exhibited good results in detecting the external seed-borne fungal infection of cucumber. Totally, five fungal genera including both saprophytic as well as pathogenic were encountered. The results indicated also the dominance of Fusarium spp. (32\%) followed by Rhizoctonia sp. (12\%). Other isolated saprophytic fungi included Alternaria sp., Helminthosporium sp. and Penicillium sp. were slightly occurred.

\section{Location of the main pathogen in the seed}

Results presented in Tab. 3 indicate that F. oxysporum was noticed in a highly infection level both in the seed coat and cotyledon, but low was recorded in the embryo. Incubation of disinfected seeds on Komada's medium permitted to Fusarium spp. to be located at the seed surface. In this case, $F$. oxysporum and $F$. solani were the most frequently fungi, whereas $F$. oxysporum invades the seed surface. On the other hand, incubation of the seeds without coats allowed to development of $F$. oxysporum only in internally located. Seed surface disinfection suppressed also the growth of saprophytic and other superficial fast growing fungi. Most of the isolated and pathogenic fungi were located on seed coat and a lower degree of infection was observed in cotyledon and embryo. F. oxysporum was also located at low frequency in embryo of the tested seeds.

\section{Identification and pathogencity tests of isolated fungi}

From the total population of fungi encountered in this study, only five genera were identified. These were $A$. alternata (Fr.) Keissler, F. oxysporum (Schlechlendahi), F. solani (Mart.) Sacc., P. italicum (Wehmer), Rhizoctonia solani (Kohn) and Helminthosporium oryzae (Tab. 2 and 4). Furthermore, the most predominant fungi detected, were $F$. oxysporum, F. solani and R. solani.

Results of the pathogenicity test presented in Tab. 5 indicate that all the isolated fungi reduced seeds variably

Tab. 2. Occurrence of seed-borne fungi in seed samples of cucumber performed by PDA and Komada media

\begin{tabular}{|c|c|c|c|c|c|}
\hline \multirow{2}{*}{ Isolated fungi } & \multirow{2}{*}{$\begin{array}{c}\text { Seed } \\
\text { treatment }\end{array}$} & \multicolumn{2}{|c|}{ PDA medium } & \multicolumn{2}{|c|}{ Komada medium } \\
\hline & & Colonies no. / 160 seeds & Occurrence (\%) & Colonies no. / 160 seeds & Occurrence (\%) \\
\hline \multirow{2}{*}{ Fusarium spp. } & - & 42.0 & 28.0 & 48.0 & 32.0 \\
\hline & + & 31.0 & 20.7 & 37.0 & 25.0 \\
\hline \multirow{2}{*}{ Alternaria sp. } & - & 8.0 & 5.3 & 0.0 & 0.0 \\
\hline & + & 1.8 & 0.7 & 0.0 & 0.0 \\
\hline \multirow{2}{*}{ Helminthosporium sp. } & - & 3.0 & 2.0 & 0.0 & 0.0 \\
\hline & + & 0.0 & 0.0 & 0.0 & 0.0 \\
\hline \multirow{2}{*}{ Rhizoctonia sp. } & - & 18.0 & 12.0 & 0.0 & 0.0 \\
\hline & + & 6.0 & 4.0 & 0.0 & 0.0 \\
\hline \multirow{2}{*}{ Penecillium sp. } & - & 9.0 & 6.0 & 0.0 & 0.0 \\
\hline & + & 0.0 & 0.0 & 0.0 & 0.0 \\
\hline
\end{tabular}

- = Non-disinfected; + = Disinfected 
Tab. 3. Location of F. oxysporum in the different seed parts of cucumber

\begin{tabular}{cccc}
\hline \multirow{2}{*}{ Seed treatment } & \multicolumn{3}{c}{ Seed component } \\
\cline { 2 - 4 } & Seed coat & Cotyledon & Embryo \\
\hline Non-disinfected & 26 & 4.1 & 0.22 \\
Disinfected & 7 & 1.3 & 0.17 \\
\hline
\end{tabular}

${ }^{*}=$ Infection level $(\%)$

of cucumber. After ten days of infection, the minimum germination was recorded in case of $F$. oxysporum treated pots $(3.3 \%)$ as compared with non-treated pots of negative control (96.7\%), followed by $F$. solani and $R$. solani. The pathogenic fungi $F$. oxysporum, F. solani and $R$. solani are transmitted from the germinated seeds to the growing seedling causing pre- and post- emergence death. The transmission rate of the tested fungi causing seed rot or pre-emergence death was higher than that causing seedling mortality. The highest percentages of seed rot or preemergence death (96.7\%), post-emergence death (15\%) and seedling mortality $(56.7 \%)$, were recorded in case of
F. oxysporum transmitted from the infected seeds. The lowest ones were in case of $H$. oryzae and $P$. italicum. Finally, all isolates of Fusarium spp. collected from seed revealed to be pathogenic to cucumber seeds (Fig. 1A) and seedlings (Fig. 1B). Symptoms on infected seedlings appeared 10 to 15 days after inoculation with $F$. oxysporum (isolate Fem8) as linear cortical lesions on died seedlings (Fig. 1B) or vascular wilt on the plants and ultimately caused seedling death. Isolate Fem8 could be then classified as F. oxysporum f. sp. cucumerinum (positive control). All the tested fungi were also re-isolated from rotted seeds and dead seedlings.

\section{Overcoming seed-borne fungi of cucumber}

A-Efficacy of some plant extracts on the condiospore germination and mycelia growth of $F$. oxysporum in vitro

Data for conidiospore germination and mycelial growth of F. oxysporum under control and effect of some plant

Tab. 4. Identification of isolated fungi from cucumber seeds and their location

\begin{tabular}{cccc}
\hline Genera & Species & Seed location & Isolate No. \\
Fusarium & F. oxysporum $($ Schlechl.) & Coat, cotyledon, embryo & Fcot2, Fco5, Fem8 \\
Flternaria & F. solani (Mart.) Sacc. & Coat & Fcol7 \\
Helminthosporium & A. alternata (Fr.) eissler & Coat & Acol1 \\
Rhizoctonia & H. oryzae & Coat & Hco9 \\
Penicillium & R. solani (Kohn) & Coat & Rcol3 \\
\hline
\end{tabular}

Tab. 5. Pathogenicity of some isolated seed-borne fungi of cucumber under greenhouse conditions

\begin{tabular}{|c|c|c|c|c|c|}
\hline \multirow{3}{*}{ Tested fungi } & \multicolumn{4}{|c|}{ Inoculated seeds } & \multirow{3}{*}{$\begin{array}{c}\text { Inoculated seedlings } \\
\text { Dead plants }(\%)\end{array}$} \\
\hline & \multirow{2}{*}{ Germination (\%) } & \multicolumn{2}{|c|}{ Emergence damping-off } & \multirow{2}{*}{ Survived plants (\%) } & \\
\hline & & Pre- & Post- & & \\
\hline F. oxysporum (Fem8) & 3.3 & 96.7 & 3.3 & 0.0 & 56.7 \\
\hline F. solani (Fco17) & 46.7 & 6.7 & 15.0 & 31.6 & 30.0 \\
\hline A.alternate (Acol1) & 73.3 & 26.7 & 0.0 & 73.3 & 10.0 \\
\hline H. oryzae (Hco9) & 81.7 & 18.3 & 0.0 & 81.7 & 6.7 \\
\hline R. solani (Rcol3) & 56.7 & 16.7 & 8.3 & 18.3 & 10.0 \\
\hline P. itallicum (Pco32) & 78.3 & 26.7 & 0.0 & 78.3 & 3.3 \\
\hline Positive control & 5.0 & 91.7 & 3.3 & 5.0 & 50.0 \\
\hline Negative control" & 96.7 & 3.3 & 0.0 & 96.7 & 0.0 \\
\hline L.S.D. 0.05 & 4.9 & 4.1 & 1.2 & 4.3 & 3.7 \\
\hline
\end{tabular}

${ }^{*}=$ Isolate of F. oxysporum f.sp. cucumerinum ${ }^{* *}=$ Soaked seeds in the SDW

Tab. 6. Efficacy of some plant extracts on the seed germination, infection by $F$. oxysporum and seeding vigor of cucumber

\begin{tabular}{cccc}
\hline Plant extract & $\begin{array}{c}\text { Germination } \\
(\%)\end{array}$ & $\begin{array}{c}\text { Infection } \\
(\%)\end{array}$ & $\begin{array}{c}\text { Vigor index } \\
(\%)\end{array}$ \\
\hline Garlic & 73.75 & 26.76 & 328.2 \\
\hline Peppermint & 96.5 & 7.14 & 472.1 \\
Rheum & 78.25 & 15.65 & 383.0 \\
Control & 43.25 & 86.34 & 87.3 \\
L.S.D. 0.05 & 11.41 & 7.17 & 57.1 \\
\hline
\end{tabular}

Tab. 7. Effect of seed treatment with peppermint oil on the seed germination, infection by F. oxysporum and seedling vigor of cucumber

\begin{tabular}{cccc}
\hline $\begin{array}{c}\text { Oil concentration } \\
(\%)\end{array}$ & $\begin{array}{c}\text { Germination } \\
(\%)\end{array}$ & $\begin{array}{c}\text { Infection } \\
(\%)\end{array}$ & $\begin{array}{c}\text { Seedling vigor } \\
\text { index }(\%)\end{array}$ \\
\hline 0 & 42.34 & 83.36 & 88.9 \\
1 & 72.18 & 20.43 & 252.6 \\
2 & 76.95 & 16.35 & 323.2 \\
3 & 83.74 & 11.41 & 468.9 \\
L.S.D. 0.05 & 14.23 & 7.12 & 43.54 \\
\hline
\end{tabular}




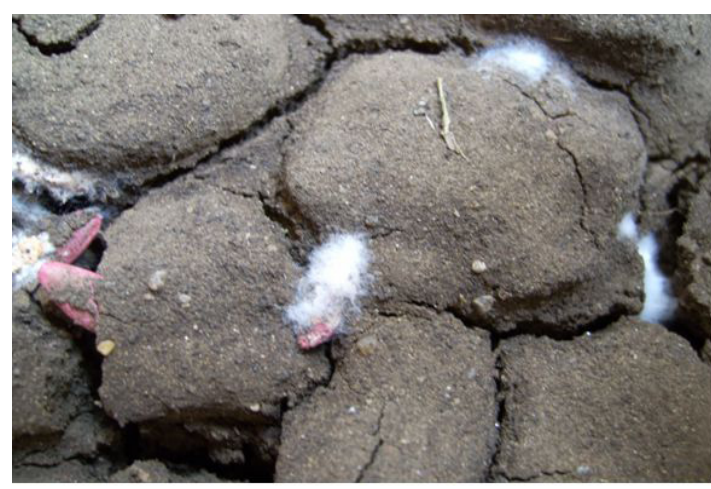

(A)

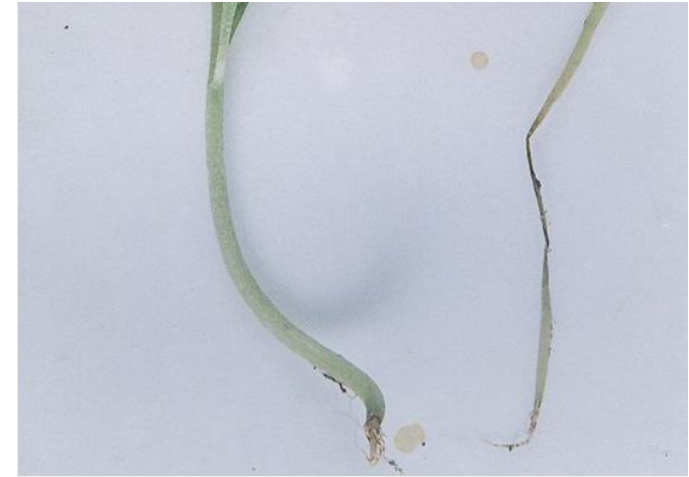

(B)

Fig. 1. Pathogenic capability of F. oxysporum (isolate Fem8), (A); The rotted seeds are covered with mycelia and (B); Cortical lesions on died seedlings (right) after 10 days of infection

extracts are presented in Fig. 2. Results indicate that the water extract of tested plants significantly varied in their effect at all tested concentrations 1,2 and 3\%. Peppermint extract was the most effective and completely inhibited spore germination and mycelial growth at conc. $2 \%$. Garlic and rheum extracts at $3 \%$ completely suppressed spore germination and mycelial growth.

\section{B-Elimination of F. oxysporum from infected seeds of} cucumber

Seed treatment with $2 \%$ peppermint extract was the most effective, where it caused a highly seed germination (96.5\%) and decreased the infection by $F$. oxysporum to $7.14 \%$ (Tab. 6). Garlic and rheum extracts at conc. $3 \%$ increased the germination to 73.75 and $78.75 \%$, respectively. Moreover, they decreased the infected plants to 26.76 and $15.56 \%$, respectively as compared with control.

\section{C-In vitro evaluation of peppermint oil by rolled towel method}

The results presented in Tab. 7 indicate that, there is a high increase in seed germination, seedling vigor and a decrease in the infection by $F$. oxysporum at all tested concentrations of peppermint oil. Seeds treated with 1,2 and $3 \%$ peppermint oil exhibited an increase in germination by

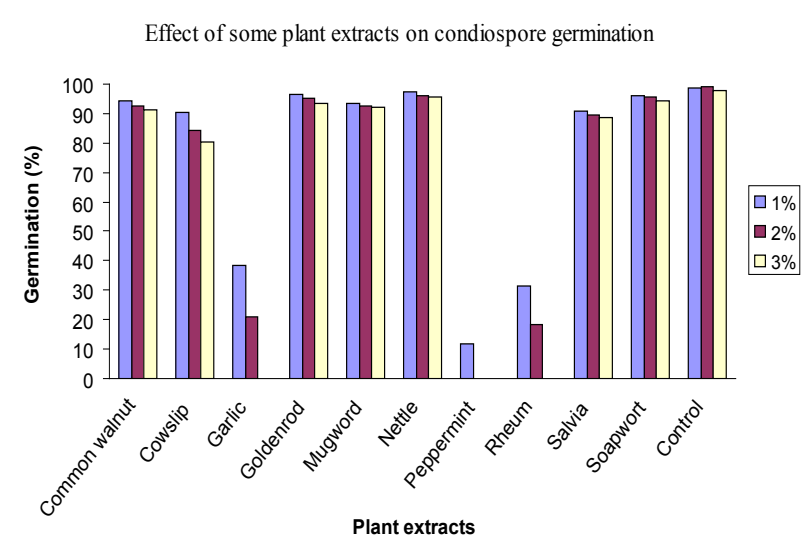

$72.18,76.95$ and $83.74 \%$, respectively, a decline in infection by $20.43,16.35$ and $11.41 \%$, respectively and increase in seedling vigor to $252.6,323.2$ and $468.9 \%$, respectively compared to control (88.9\%).

\section{D-In vitro evaluation the vapour phase of peppermint oil}

Highly significant reduction was occurred in the percentage of pre- emergence damping-off when cucumber seeds were evaporated by the vapor phase of peppermint oil (10 and $15 \mu \mathrm{l} / 400 \mathrm{ml}$ air) before sowing (Tab. 8). Seeds, which failed to germinate, were found to be covered with the fungal mycelium (Fig. 1A). On the other hand, the same treatments caused complete protection against postemergence damping-off. The survival rate of the plants was also increased by 81.7 and $86.7 \%$, respectively compared with control.

\section{Discussion}

Many important diseases of plants are caused by seedborne fungi (Basak and Woong Lee, 2002; Littke, 1996; Nasreen et al., 2009; Neergaard, 1977). These diseases have shown variable trends over the years with huge loss in total crop production. Another adverse effect of these

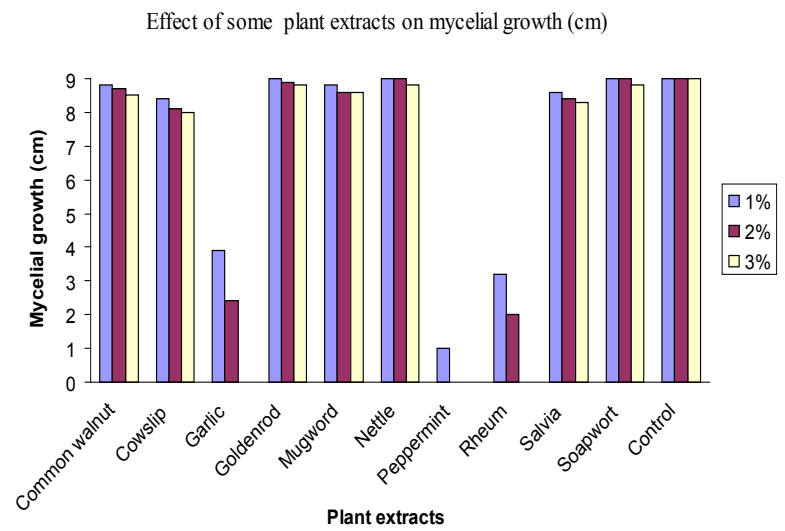

Fig. 2. Efficacy of some plant extracts on spore germination and mycelial growth of $F$. oxysporum in vitro 
pathogens is that they were spreading to new areas. These emphasize the need for viable, healthy and pathogen free seeds. In order to increase the production of cucumber qualitatively and quantitatively, farmers require healthy and quality seeds with a high germination and purity. Hence, it is imperative that the seeds must be tested before sowing in the field. Further, it necessitates seed health and free from seed-borne diseases are constantly desired with the eradication of seed-borne inocula through various seed treatments. Occasionally, seedling loss may originate from poor germination or pre-emergence disease. An understanding of the origin and nature of seed-borne fungi may be helpful in reducing losses and improving yields. Therefore, seed health testing for presence of these seed-borne pathogens is an important step in the management of crop diseases. Due to climate change, emerging, re-emerging and endemic plant pathogens continue to be a challenge in safeguarding plant health in Egypt. Therefore, early and accurate diagnoses and pathogen surveillance will allow time for development and application of seed treatments. Several methods have been developed to detect the seedborne microflora in seed lots (Begum and Momin, 2000; Boughalleb and El Mahjoub, 2006; Jeffrey et al., 1985; Kunwar et al., 1986; Krishnappa and Shetty, 1990; Moore, 1984; Neergaard, 1956; 1977; Raut, 1987; Sadashivaiah et al., 1986; Shahda et al., 1995;). The emphasis has been on methods, which are simple, easy, economic, sensitive, reproducible and efficient, but some methods such blotter and deep freezing suppress seed germination (Limonard, 1968). The results in this study indicate that PDA medium exhibited good results in detecting the seed surface pathogens of cucumber, whereas. Komada selective medium was better in detecting Fusarium spp., on seed samples. The results of the present study are in accordance with those reported by Boughalleb and El Mahjoub (2006) where the dominance of Fusarium spp. followed by $R$. solani in all tested seed lots have been reported.

The seed-borne pathogen may be present externally or internally or also associated with the seed as contaminant. This pathogen may cause a seed abortion and rot, necrosis, reduction and elimination of germination capacity as well as seedling damage at later stages of plant growth resulting in development of the disease as systemic or local infection (Bateman and Kwasna, 1999; Khanzada et al., 2002). The seed-borne fungi are known to be located in different parts of the seeds. Results obtained in this study showed that $F$. oxysporum occurred mainly in both seed coat and cotyledon, but at low levels in embryo of cucumber seeds. These results are in agreement with those obtained by Boughalleb and El Mahjoub (2006).

The results of the present study also indicates the incidence of six fungi in cucumber seeds including $A$. alternata, F. oxysporum, F. solani, $R$. solani, $H$. oryzae and $P$. itallicom. All these isolated fungi reduced seeds variably and only $F$. oxysporum caused a highly reduction in seed germination. Fusarium oxysporum, F. solani and $R$. solani are transmitted from seeds to seedlings and caused pre- and post- emergence death. Kabeere et al. (1997) reported that the transmission of Fusarium subglutinans from maize seeds to seedlings from non-surface-disinfected and surface-disinfected seeds, respectively, which were similar to the respective seed-borne inoculum levels, suggesting that under favorable conditions the fungus may be effectively transmitted from seeds to seedlings. The present study showed that the transmission rate from seeds to seedlings of the tested fungi which causing pre-emergence death was higher than that causing seedling mortality. The highest percentages of pre-and post- emergence death and seedling mortality were recorded in case of $F$. oxysporum transmitted from the infected seeds. Basak and Lee (2002) also reported similar results in case of seed-borne fungi of maize.

Recently, several studies have reported the use of plant extracts in controlling fungal pathogens (Ja Choi et al., 2004; John Sudhakar, 2002; Satish et al., 2010; Stephan et al., 2005). The present study showed that water extracts of the tested plants significantly varied in their effect on controlling F. oxysporum at all tested concentrations. Peppermint extract was the most effective in completely inhibiting spore germination and mycelial growth at conc. $2 \%$. These results are in agreement with those reported by Ghorbany et al. (2010) where garlic and rheum extracts completely suppressed spore germination and mycelial growth of Fusarium at conc. 3\%. Yi et al. (2009) reported that that garlic bulb extract at $0.625 \%$ completely controlled $F$. oxysporum f.sp.cucumerinum and Pythium aphanidermatum and significantly enhanced seed germination, seedling growth and vigor of cucumber. For safe elimination of $F$. oxysporum from seeds of cucumber, application of these extracts, paper towel method was used. The results in this study indicated that seed treatment with $2 \%$ peppermint extract was the most effective and caused high seed germination, decreased infection rate and improved seedling growth. Several studies have tested the same or different plants in controlling Fusarium pathogen on other crops and found similar effect (Agbenin and Marley, 2006; ElMougy Nehal and Alhabeb, 2009; Gorbany et al., 2010; Morsy et al., 2009). Cucumber seeds treated with 1,2 and $3 \%$ peppermint oil exhibited higher seed germination and a marked decrease in the infection incidence resulting in and increased seedling Vigor. Kritzinger et al. (2002) reported that peppermint oil significantly inhibited the storage fungi including $F$. oxyspourm on the white cowpea seeds thereby increasing the percentage germination and emergence. Results also showed that evaporated seeds by vapors of peppermint oil before sowing caused a marked reduction of pre-emergence damping-off and complete protection against post- emergence damping-off. The survival plants were also increased. Finally, seed treatment may not only protect seeds but may also colonize and protect roots and increase the plant growth. Further research into these extracts will identify the active compounds responsible for their fungicides activity. 
90

\section{Acknowledgement}

Authors are thankful to all members of experimental farm, faculty of agriculture, Sohag University and south Valley Univ. for their financial support to carry out the research work.

\section{References}

Abdul Baki AA, Anderson JD (1973). Vigour estimation in soybean seeds multiple criteria. Crop Sci 13:630-633.

Agbenin ON, Marley PS (2006). In-vitro Assay of some plant extracts against Fusarium oxysporum f. sp. lycopersici causal agent of tomato wilt. J of Plant Protec Res 46(2):215-220.

Amin ABMR, Rashid MM, Meah MB (2009). Efficacy of garlic tablet to control seed-borne fungal pathogens of cucumber. J Agric Rural Develop 7:135-138.

Antoniou PP, Tjamos EC (2010). Control of Fusarium oxysporum f. sp. cucumerinum of cucumbers by soil solarization with impermeable plastics and/or reduced doses of methyl bromide. EPPO Bulletin 30(2):165-167.

Anonymous (1996). International Rules for Seed Testing. Seed Science and Technology, Association, 68-72 p.

Barnett HL, Hunter BB (1972). Illustrated Genera of Imperfect Fungi. Burgess Publication Ltd. St. Paul, Minnesota, USA, $241 \mathrm{p}$.

Barrera-Necha LL, Garduno-Pizana C, Garcia-Barrera LJ (2009). In vitro antifungal activity of essential oils and their compounds on mycelial growth of Fusarium oxysporum $\mathrm{f}$. sp. gladioli (Massey) snyder and hansen. Plant Pathol J 8(1):1722.

Basak AB, Woong Lee M (2002). Prevalence and transmission of seed-borne fungi of maize grown in a farm of Korea. Mycobiol 30(1):47-50.

Bateman GL, Kwasna H (1999). Effects of number of winter wheat crops grown successively on fungal communities on wheat roots. Appl Soil Ecol 13:271-282.

Begum HA, Momin A (2000). Comparison between two detection techniques of seed-borne pathogens in cucurbits in Bangladesh. Pak J Sci Ind Res 43:244-248

Belabid L, Simoussa L, Bayaa B (2010). Effect of some plant extracts on the population of Fusarium oxysporum f. sp. lentis, the causal organism of lentil wilt. Adv Environ Biol 4(1):95100.

Blancart D, Lecoq H, Pitrat M (1991). Cucurbits diseases, survey, identify, control. Revue Horticole, INRA, (in French).

Boughalleb N, Armengol J, El Mahjoub M (2005). Detection of races 1 and 2 of Fusarium solani f. sp. cucurbitae and their distribution in watermelon fields in Tunisia. J Phytopathol 153:127-133.

Boughalleb N, El Mahjoub M (2006). In vitro detection of Fusarium spp. infection on watermelon seeds and their localization. Plant Pathol J 5(2):178-182.

Champion R (1997). Identify fungi transmitted by seeds.
INRA, (in French).

Domsch KH, Gams W, Traute-Heidi Anderson (1980). Compendium of soil fungi. Academic Press. A Subbsidiary of Harcourt Brace Jovanovich, Publishers, London, 1:859 p.

Ellis MB (1971). Demataceous Hyphomycetes, Commonwealth Mycological Institute, Ferry Lane, Kew, Surrey, U.K, 680 p.

El-Mougy Nehal S, Alhabeb RS (2009). Inhibitory effects of powdered caraway and peppermint extracts on pea root tot under greenhouse conditions. J Pl Protect Res 49(1):90-96.

Fakir GA (1983). Teaching, research and training activities on seed pathology in Bangladesh. Seed Sci Technol 11:13451352.

Farrag Eman SH, Fatouh YO (2010). Solarization as a method for producing fungal-free container soil and controlling wilt and root-rot diseases on cucumber plants under greenhouse conditions. Arch Phytopathol Plant Prot 43(6):519-526.

Farshabaf Moghadam M, Omid Beygi R, Pourbaig MVM, Ghaemi A (2004). Composition and antifungal activity of peppermint (Mentha piperita) essential oil. Iran J Pharm Res (IJPR) 3(supplement 2):68-69.

Gargouri S, Hajlaouri MR, Abdennadher M, Marrakchi M (2000). Isolation and morphological and molecular identification of Fusarium spp. transmitted by watermelon seeds. Bull OEPP/EPPO Bull 30:217-222 (in French).

Ghorbany M, Jafarpour B, Rastegar MF (2010). Application of some plant products to control of Fusarium oxysporum f.sp. cumini causing cumin wilt. J Plant Prot 24(1):1.

Gomez KA, Gomez AA (1984). Statistical Procedures for Agricultural Research. John Wiley \& Sons, Singapore, 139-153 p.

Gunther E (1948). The essential oil. Vol 1. Van Nostran, Princeton, New York, $774 \mathrm{p}$.

Habib A, Sahi ST, Ghazanfar MU, Ali S (2007). Location of seed-borne mycoflora of Eggplant (Solanum melongene L.) in different seed components and impact on seed germinability. Inter J Agric Biol 9(3):414-416.

Ja Choi G, Soo Jang K, Kim J, Lee S, Cho J, Cho K, Kim J (2004). In vivo Antifungal Activities of 57 Plant Extracts against Six Plant Pathogenic Fungi. Plant Pathol J 20(3):184-191.

Jeffery KK, Lipps PE, Herr LJ (1985). Seed-treatment fungicides for control of seed-borne Alternaria helianthi on sunflower. Plant Dis 69:124-126.

John Sudhakar M (2002). Studies on integrated management of charcoal rot of maize caused by Macrophomina phaseolina (Tassi.) Goid. with special reference to biological control. MSc. Thesis, Univ of Agric Sci, Dharwad, 110 p.

Kabeere F, Hill MJ, Hampton JG (1997). The transmission of Fusarium subglutinans from maize seeds to seedlings. Austral Plant Pathol 26(2):126-130.

Karim M (2005). Prevalence of fungi associated with seeds of some minor cereals. MSc. Thesis. Depart of Plant Pathol, Bangladesh Agric Univ, Mymensingh, 97 p.

Khare MN (1996). Methods to test seeds for associated fungi. Indian Phytopathol 49: 319-328. 
Khanzada KA, Rajput MA, Shah GS, Lodhi AM, Mehboob $F$ (2002). Effect of seed dressing fungicides for the control of seed-borne mycoflora of wheat. Asian J Plant Sci 1:441444.

Komada H (1975). Development of a selective medium for quantitative isolation of Fusarium oxysporum from natural soil. Rev Plant Protect Res 8:114-125.

Krishnappa M, Shetty HS (1990). Location of Alternaria species in sunflower seeds. Plant Dis Res 5:203-204.

Kritzinger Q, Aveling AS, Marasas WFO (2002). Effect of essential plant oils on storage fungi, germination and emergence of cowpea seeds. Seed Sci Technol 30(3):609-619.

Kunwar IK, Singh T, Machado CC, Sinclair JB (1986). Histopathology of soybean seed and seedling infection by Macrophomina phaseolina. Phytopathol 76:532-535.

Limonard J (1968). Ecological aspects of seed health testing. Internat Proc of Seed Testing Assoc 33:343-513.

Littke W (1996). Seed Pathogens and Seed Treatments, $187-$ 191 p. In: Landis TD, South DB (Eds.). Technol Cords. National Proceedings, Forest ad Conservation Nursery Associations. Gen. Tehn. Rep.PNW-GTR-389. Portland, OR: US. Depart of Agric, Forest Service, Pacific Northwest Research Station.

Maden S, Singh D, Mathur SB, Neergard P (1975). Detection and location of seed borne inoculum of Ascochyta rabei and its transmission in chickpea. Seed Sci Technol 3:667-671.

Martyn RD, Bruton BD (1989). An initial survey of the United States races of Fusarium oxysporum f. sp. niveum. Hort Sci 24:696-698.

Michail SH, Sheir HM, Rasmy MR (1989). Cross protection of watermelon and cucumber plants against wilt by prior inoculation with an irrespective forma specialis of Fusarium oxysporum. Acta Phytopathol Entomol Hunga 24:301-309.

Michail SH, Rehim MAA, Tarabeig AM, Aly MA (2002). Effect of seed-borne infection levels on watermelon wilt incidence. Acta Phytopathol Entomol Hungarica 37:347-351.

Moore WF (1984). Stem canker and charcoal rot. Proc Annual Soybean Res Conf 14, Washington DC, USA.

Morsy SM, Elham A Drgham, Mohamed GM (2009). Effect of garlic and onion extracts or their intercropping on suppressing damping-off and powdery mildew diseases and growth characteristics of cucumber. Egypt J Phytopathol 37(1):3546.

Nasreen S, Azeem T, Ghaffar A (2009). Location of seeds-borne inoculum of Macrophomina phaseolina and its transmission in seedlings of cucumber. Pak J Bot 41(5):2563-2566.

Neergaard P (1956). Plant Protection Service, Copenhagen, 17 p.

Neergaard P (1977). Seed Pathology, Vol I and II, MacMillan Press, London, U.K, 1187 p.

Neergaard P (1979). Seed Pathology. Vol 1. The Macmillan Press Ltd., 839 p.
Nostro A, Germanò MP, Angelo VD', Marino A, Cannatelli MA (2000). Extraction methods and bioautography for evaluation of medicinal plant antimicrobial activity. Lett Appl Microbiol 30:379-384.

Patel KK, Patel AJ (1990). Control of charcoal-rot of sesame. Ind J of Mycol Plant Pathol 20:62-63.

Pimentel D, Levitan L (1986). Pesticides: amounts applied and amounts reaching pests. BioScience 36:86-91.

Prasad RD, Kulshreshta DD (1999). Acetone infusion of fungicides in sunflower seed for the control of Alternaria helianthi. Seed Res 27:217-219.

Raut JG (1987). Detection of Macrophomina phaseolina in sunflower seeds. Seed Res 15:102-103.

Raut JG (1978). Transmission of seed borne Macrophomina phaseolina in sunflower seed. Sci Technol India 11:807-814.

Sadashivaiah AS, Ranganathaiah G, Nanje Gowda D (1986). Seed health testing of Helianthus annuus with special reference to Macrophomina phaseolina. Ind Phytopathol 39:445447.

Sahayaraj K, Borgio JF, Raju G (2009). Antifungal activity of three fern extracts on causative agents of groundnut early leaf spot and rust diseases. J Plant Protect 49(2):141-144.

Satish S, Raghavendra MP, Raveesha KA (2010). Management of seed-borne fungal pathogens of sorghum seeds by aqueous extract of Lawsonia inermis L. J of Biopesticides 3(1):237-241.

Shahda WT, Al-Rahma ANAN, Rageh SA (1995). Dampingoff of some cucurbitaceous crops in Saudi Arabia with reference to control methods. J Phytopathol 143:59-63

Shakir AS, Mirza JH, Sahi ST, Ahmad F (1995). Detection of seed-borne fungi associated with sponge gourd (Luffa cylindrical (L.) Roem.), their location in different seed components and their control. Pak J Phytopathol 7:140-144.

Singh RD, Kaiser SA (1995). Evaluation of some systemic and non-systemic fungicides against the charcoal rot pathogen Macrophomina phaseolina (Tassi) Goid. of maize. J Tropical Agric 33:54-58.

Stephan D, Schmitt A, Carvalho SM, Seddon B, Koch E (2005). Evaluation of biocontrol preparations and plant extracts for the control of Phytopthora infestans on potato leaves. Eu J Plant Pathol 111:1-12.

Taylor E, Bates J, Kenyon D, Maccaferri M, Thomas J (2001). Modem molecular methods for characterization and diagnosis of seed-borne fungal pathogens. J Plant Pathol 83:7581.

Yi LC, Rui ZC, Hui CZ (2009). Inhibitory effects of freshly crushed garlic (Allium sativum L.) extract on seed-borne pathogens of cucumber (Cucumis sativus L.) and allelopathy functions. J Northwest A \& F Univ-Natural Sci Ed 37:140144. 